\title{
The ALA Task Force on Gay Liberation: Effecting Change in Naming and Classification of GLBTQ Subjects
}

\author{
Melissa A. Adler, PhD \\ School of Library and Information Studies \\ University of Wisconsin-Madison \\ 600 N. Park St. \\ Madison, WI 53703 \\ madler@wisc.edu
}


Adler, M. (2013). The ALA Task Force on Gay Liberation: Effecting Change in Naming and Classification of GLBTQ Subjects. Advances In Classification Research Online, 23(1), pp. 1-4. doi:10.7152/acro.v23i1.14226 


\section{EXTENDED ABSTRACT}

The American Library Association's Task Force on Gay Liberation was the first professional organization in the U.S. to formally organize to protect rights and promote awareness of gays and lesbians. Founded in 1970, the Task Force has evolved to become the Gay Lesbian, Bisexual, and Transgendered Round Table (GLBTRT) of the A.L.A. In this paper I will discuss the influence of key members of the group, such as Barbara Gittings, Steve Wolf, Joan Marshall, and Michael McConnell, on Library of Congress classifications and subject headings. I will also discuss how the success and momentum of this agenda depended on the efforts of Sanford Berman, who advised the Task Force and pushed for revisions of gay and lesbian subject headings and classifications. This study significantly informs current classification research, as it documents the beginning of a movement to democratize subject cataloging practices. The actions taken by the Task Force and its individual members broke new ground, and arguably, led to present-day participatory, user-centered classification practices, such as social tagging.

At the 1971 A.L.A. annual conference in Dallas, Texas, the Task Force announced the first winner of its Gay Book Award and conducted its first formal program: "Sex and the Single Cataloger: New Thoughts on Some Unthinkable Subjects," featuring librarian panelists Joan Marshall and Steve Wolf. Marshall and Wolf's panel was one of the earliest public criticisms of the Library of Congress's treatment of gay and lesbian subjects. At that meeting, after hearing gay library worker Michael McConnell describe the legal battle surrounding his employment at the University of Minnesota, Task Force members insisted that A.L.A. Council, members, and the Intellectual Freedom Committee respond to his experience of job discrimination. McConnell and his partner, Jack Baker, were the first gay couple to apply for a marriage license in Minnesota in 1970 and in response, the University terminated his position. Shortly after this, McConnell became a cataloger at Hennepin County Public Library, working with Sanford Berman and actively influencing cataloging practices.

Wolf, a librarian at the University of Massachusetts in Boston, credited the Task Force with precipitating change in the Library of Congress Classification in 1972: “After agitation by the cataloging sect of SRRT's Task Force on Gay Liberation, LC pulled 'Homosexuality' from the shadow of 'Sexual deviations' into the clear descriptive light of 'Sexual life" (Wolf 1972, 42). That same year the subject heading "Sexual Deviation" replaced "Sexual Perversion."
Renowned for her gay activism outside of librarianship, Barbara Gittings became the second coordinator of the Gay Liberation Task Force in 1972. Among the Task Force's achievements under her leadership were the publication of bibliographies of gay-positive books, and expansion of the Gay Book Award, now known as the Stonewall Book Award. Although Gittings was not a librarian, she is often regarded as the most influential member of the Task Force. Her activism outside of A.L.A. included testifying before the American Psychiatric Association, along with Frank Kameny. Their efforts led to the removal of homosexuality as a mental disorder from the DSM in 1972, thereby influencing cataloging and classification practices for gay subjects.

The Gay Book Awards and bibliographies signaled and contributed to an emerging field, and the creation of new subjects and classifications firmly placed the growing discipline in the catalog and on the shelves. Gender and sexuality scholars, audiences, and librarians demanded that subject headings be based on their terms, rather than those of medical professionals who had historically pathologized homosexuality. Together, activist librarians and scholars had an incredible impact on the classification of GLGBT subjects, beginning in the early 1970s, as part of the wider Gay Liberation Movement.

\section{REFERENCES}

Berman, S. (1971). Prejudices and antipathies: A tract on the LC subject heads concerning people. Metuchen, NJ: Scarecrow Press.

Gittings, B. (1998). Gays in library land: The Gay and Lesbian Task Force of the American Library Association: The first sixteen years. In J.V. Carmichael, Jr. (Ed.). Daring to find our names: The search for lesbigay history (pp. 81-93) Westport, CT: Greenwood Press.

Gough, C. (1998). The Gay, Lesbian, and Bisexual Task Force of the American Library Association: A chronology of activities, 1970-1995, In J.V. Carmichael, Jr. (Ed.). Daring to find our names: The search for lesbigay history (pp. 123-132) Westport, CT: Greenwood Press.

Greenblatt, E. (1991). Homosexuality: The evolution of a concept in the Library of Congress Subject Headings." In C. Gough and E. Greenblatt. (Eds.), Gay and lesbian 
library service (pp. 75-101) Jefferson, NC: McFarland.

Kameny, F. (2002). Government v. gays: Two sad stories with two happy endings, civil service employment and security clearances.” In J. D'Emilio, W.B. Turner, \&

Marshall, J. (1977). On equal terms: A thesaurus for nonsexist indexing and cataloging. New York, NY: Neal-Schuman Publishers,.

Marshall, J. (1972). LC labeling: an indictment. In C. West and \& E. Katz (Eds.), Revolting Librarians (pp. 45-49). San Francisco, CA: Booklegger Press.

Olson, H. A. (2000). The Power to Name: Locating the Limits of Subject Representation in Libraries. Boston, MA: Kluwer Academic Publishers.
Passett, J. (2008). Sex variant woman: The life of Jeannette Howard Foster. Philadelphia, PA:

U. Vaid.DEQSapodPeeding change: Sexuality, public policy, and civil

Samek, T. (2001). Intellectual freedom and social responsibility in American librarianship, 1967-1974. Jefferson, NC: McFarland.

Wolf, S. (1972). Sex and the single cataloger: New thoughts on some unthinkable subjects. In C. West and \& E. Katz (Eds.), Revolting Librarians (pp. 39-44). San Francisco, CA: Booklegger Press. 